\title{
IMPACT OF WATER-LEVEL FLUCTUATION IN REDHILLS RESERVOIR ON POPULATION DYNAMICS OF CHENNAI CITY
}

\author{
Venkatesan D \\ Assistant professor, Department of Geology, \\ AVS College of art and science, Salem, \\ Tamil Nadu, India
}

\begin{abstract}
Water-level fluctuations are a natural phenomenon that occurs in almost all aquatic ecosystems. With the increased population growth the world has seen in recent years, the resources that were once plentiful are becoming scarcer. Human-induced stressors such as increasing consumptive use of water are often linked to regions with significant growth in population. These stressors have the effect of lowering lake levels and reducing downstream flows, a major area of concern because of adverse economic and environmental impacts associated with progressive lowering of water levels.

Chennai's water resources have been increasingly stressed by climate change and population growth. The secondary data (2007 to 2013$)$ were collected from the Chennai Metro Water and sewage board for this analysis. Assessment of long-term impacts of projected changes in climate, population, land use and land cover, and groundwater availability on local water resources is critical to sustainable development. Water level depletion led to a drought. In this paper, an attempt has been made to investigate the groundwater level fluctuation with respect to nearby reservoir water level depletion and rainfall variability and also studying the water scarcity in Chennai city.
\end{abstract}

Keywords - Redhills, Chennai water scarcity, Environmental Impact, Human Activities

\section{INTRODUCTION}

A reservoir is a natural or artificial lake, storage pond or impoundment from a dam which is used to store water. Reservoirs are constructed in a river valley by excavation in the ground or by conventional construction techniques such as brickwork or cast concrete. The reservoir used to describe naturally occurring underground reservoirs such as those beneath an oil or water well.

Water scarcity is an inadequate natural water resource to supply a region's demand, and economic water scarcity is a result of poor management of the sufficient water resources which influence every continent and around 2.8 billion people throughout the world at least one month out of every year. Above 1.2 billion people lack access to clean drinking water [1]. It is also a result of two mechanisms: physical water scarcity and economic water scarcity.

Today Hydrologists assess water scarcity by looking at the population-water equation. This is the result of comparing the amount of total available water resources per year to the population of the region. The most popular approach to measuring water scarcity has been to rank countries according to the number of annual water resources available per person. the Falkenmark Water Stress Indicator [2] denotes a country is said to experience "water stress" when annual water give drop below 1,700 cubic meters per person per year. The value between 1,700 and 1,000 cubic meters per person per year, periodic or limited water shortages can be expected. If the water supplies below 1,000 cubic meters per person per year, the country faces "water scarcity"[3].

The global population is growing up by 80 million people annually, increasing the demand for fresh water by about 64 billion $\mathrm{m} 3$ a year [4]. Actually, water withdrawals tripled over the last 50 years due to population growth [5]. This rapid rate of growth also caused the potential global availability of water to decline from $12,900 \mathrm{~m} 3$ per capita per year in 1970 , to $9,000 \mathrm{~m} 3$ in 1990 , to about 7,000 m3 in 2000 [6].

Physical, chemical and biological features in reservoirs are influenced by seasonal surface-level fluctuations, which are significantly associated with anthropogenic utilization (Wetzel 1990) [7]. Such fluctuations are more frequent in reservoirs located in regions where rain events are strongly seasonal and occur in an irregular precipitation regime. In this area, local human populations intensively use the water stored in most of those reservoirs for urban water, irrigation, and recreation. In spite of the current belief that water level fluctuations exert an influence on water quality, conditioning its use, there are few studies directed to understanding the mechanisms by which those hydrological patterns can influence reservoir dynamics. Consequently, 


\section{International Journal of Engineering Applied Sciences and Technology, 2019 Vol. 4, Issue 3, ISSN No. 2455-2143, Pages 99-104 \\ Published Online July 2019 in IJEAST (http://www.ijeast.com)}

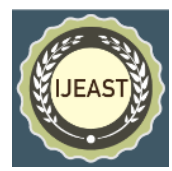

there is a paucity of basic information, which is required for effectively managing reservoirs subject to periodic water level fluctuations. Water levels are based on the water cycle, as the balance between precipitation, drainage, and evaporation determines how much water is held within a lake and where the water meets the shore. Lake levels change when precipitation exceeds or is below average. As water levels rise and fall, lake and shore ecosystems, as well as people living within the region, are affected. Water scarcity mainly depends on water stress, water shortage, and water crisis and also the concept of water stress is relatively new, it is the difficulty of obtaining sources of fresh water for use during a period of time and may result in further depletion and deterioration of available water resources [8].Water shortages caused by climate change, such as altered weather patterns such as droughts or floods, increased pollution, human demand and overuse of water [9]. A water crisis is a state where the available potable, unpolluted water within a region is less than that region's demand. Water scarcity is also done by growing freshwater use and depletion of usable freshwater resources.

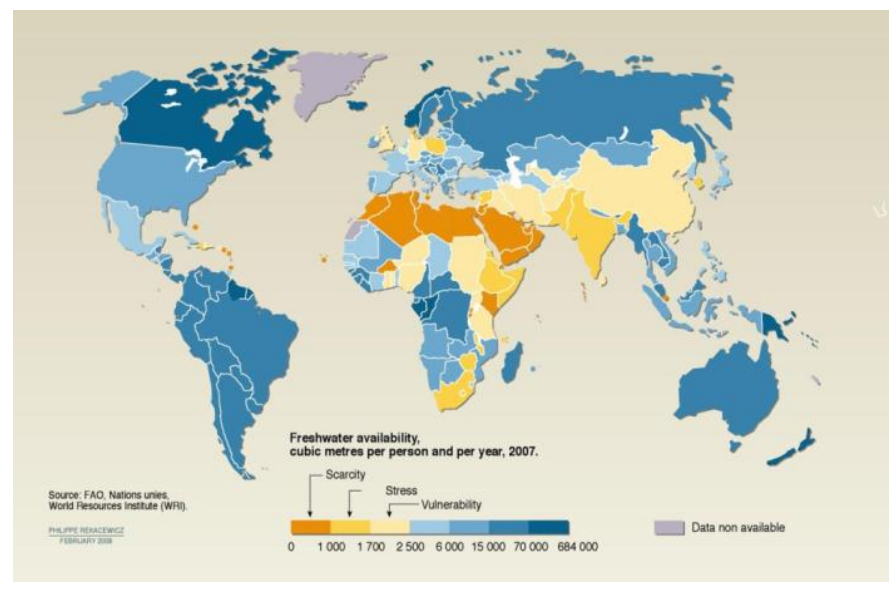

Fig. 1. World freshwater availability

Chennai's water supply system is primarily dependent on the Red Hill Reservoir, Cholavaram Tank, Poondi Chennai is divided as being in Seismic Zone III which is indicating a risk of damage from earthquakes [11]. The city falls in the geotectonic zone, so the city is considered a potential geothermal energy site. The crust has granite rocks representing volcanic activities in the past. It is expected that temperatures of around $200-300{ }^{\circ} \mathrm{C}$ will be available if the ground were drilled 4 to $5 \mathrm{~km}$ deep. The region has the oldest rocks in the country dating back to nearly a billion years [12].

Reservoir and partly on the Chembarambakkam Tank. These reservoirs are fed by monsoon runoffs and can store up to 210 million cubic meters of water for use later in the year. The Chennai Metropolitan Water Supply and Sewerage Board (Metro Water) (CMWSSB) has estimated that these reservoirs can provide a safe yield of 200 million liters per day if completely filled. Several local aquifers are the sources of groundwater that supplement existing surface water storage.

Previously, Redhills Lake was used as an Irrigation lake. The lake and its water were made to quench the thirst of Chennaities right from the year 1868. This lake gets its supply from Poondi Reservoir and the Cholavaram Lake, through its Upper and Lower Supply Channels. Thus the irrigation utility was stopped. Poondi Reservoir and Sembaramapkkam Lakes combined to form Kandaleru (Telugu Ganga Project). The Red Hills Lake is made to fill on both sides apart from the rainwater from the Catchment areas. Compared Poondi and Cholavaram Lakes, red hill lake water catchment area is around $7.5 \mathrm{~K}$. Ms and with much storage capacity.

\section{STUDY AREA}

Puzhal Eri, also called as the Red Hills Lake, is located in Ponneri Taluk of Thiruvallur district, Tamil Nadu, South India. It is situated near Chennai. This name has come from the red hills (Semman Kuviyal) that were mostly present in this area in the early stage. Red Hills is located on "Sengundram" which is one of the most densely populated towns in Tamil Nadu. The study area, namely the Red Hills (Fig. 1), situated near Chennai, India is located $13^{\circ} 09^{\prime} 58.0^{\prime \prime} \mathrm{N}$ $80^{\circ} 10^{\prime} 44.3^{\prime \prime} \mathrm{E}$ with an elevation ranging from 0 to $42 \mathrm{~m}$ above MSL (Mean Sea Level). The watershed collects an annual average rainfall of $152.42 \mathrm{~mm}$ and more than $80 \%$ of the rainfall is received during the NE monsoon (OctoberDecember). The temperature range varies from minimum and maximum of $22^{\circ} \mathrm{C}$ to $39^{\circ} \mathrm{C}$. The Red hill reservoir filled by watershed has a maximum capacity of 94.45 MCM [10]. North East Monsoon period received $52 \%$ and $41 \%$ has been received during the South West Monsoon period.

Puzhal Lake is one of the two rain-fed reservoirs from where water is drawn for supply to Chennai City, the other one being the Chembarambakkam Lake and Porur Lake. The capacity of the lake is 3,300 million $\mathrm{ft}^{3}$ (93 million $\mathrm{m}^{3}$ ). Redhills Lake is named as Puzhal Lake and it is a major water reservoir for the city. Thiruvallur district is bounded on the north by Andhra Pradesh state, on the east by the Bay of Bengal, on the southeast by Chennai district, on the south by Kanchipuram and on the west by Vellore district. The coastal area of the district is mostly flat and dreary; other parts it is undulating and even hilly in some places.

\section{Methodology}

Reservoir storage details collected from the Chennai Metropolitan Water Supply \& Sewerage Board (http://www.chennaimetrowater.tn.nic.in/) within this storage data preparing histogram of reservoir outflow and reservoir 


\section{International Journal of Engineering Applied Sciences and Technology, 2019 Vol. 4, Issue 3, ISSN No. 2455-2143, Pages 99-104 \\ Published Online July 2019 in IJEAST (http://www.ijeast.com)}

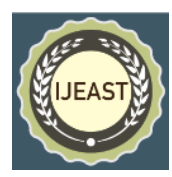

water level fluctuation. The secondary data collected in the month of May and September from 2007 to 2013 were used for the present investigation. Rainfall data in the year of 2006 to 2013 collected for our study area. On the other side, 63 years Chennai population collected from the Census of India and groundwater fluctuation and rainfall data from online as secondary data. From the reservoir details preparing histograms by using Ms-excel.

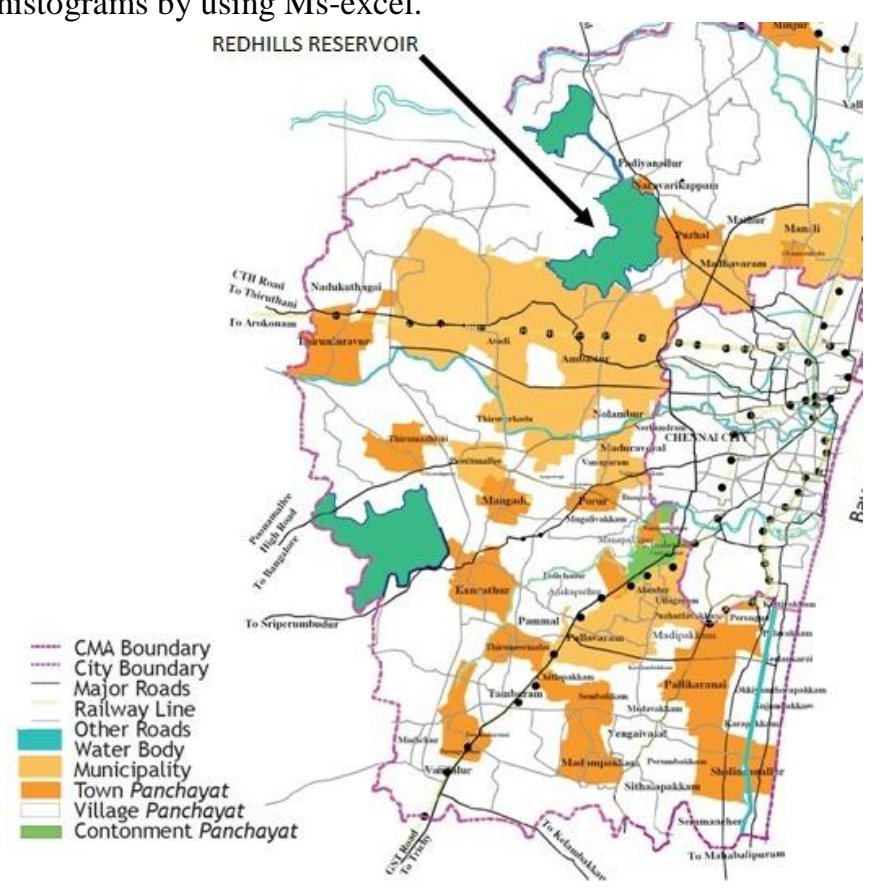

Fig. 2. Study area

\section{RESULT AND DISCUSSION}

The increasing trend of Population in Chennai

According to the 2001 census, the Population of Chennai was 4.2 million $(4,216,268)$. The population density in the city was 24,682 per $\mathrm{km}$ so that it is one of the most densely populated cities in the world [16]. Chennai has a good sex ratio of 951 females per 1000 males in the last census which currently stands at 986 . Also, the Literacy rate in the City has improved a lot as compared to the last census. The average literacy rate in the city is also very higher at $80.14 \%$ as compared to an overall literacy rate of India which is only $64.5 \%$. Chennai is rated at the fourth position in terms of the slum population of India. The city is home to 820,000 slum people (Census 2001) living in slum conditions.

Chennai with a current population of 4,792,949 (4.7 million) is one of the largest cities of South India. The Population density of Chennai city is 26903, which is currently highest in the state of Tamil Nadu [13]. Chennai has witnessed tremendous growth in its manufacturing, retail, health care and IT sector in the last 10 years. It is observed as India's fourth largest city after Delhi, Mumbai, and Kolkata. Because of a major business area of the state, the population of Chennai has witnessed enormous growth in its Population (Table. 1). It has become an important location for trade and tourism in recent years. Chennai city has tremendous potential for industrial growth because of its economic viability and available infrastructure [14].

Table -1 Population data Chennai

\begin{tabular}{|c|c|}
\hline \multicolumn{2}{|c|}{ Growth of Population in Chennai } \\
\hline Year & Population* \\
\hline 1951 & $1,416,056$ \\
\hline 1961 & $1,729,141$ \\
\hline 1971 & $2,469,449$ \\
\hline 1981 & $3,266,034$ \\
\hline 1991 & $3,841,398$ \\
\hline 2001 & $4,343,645$ \\
\hline 2011 & $4,681,087$ \\
\hline 2012 & $4,717,599$ \\
\hline 2013 & $4,754,499$ \\
\hline
\end{tabular}

The state government departments are growing towards increasing trade and commerce links with other countries and developing greater industrial growth [15]. This entire trade boom in the business of Chennai city accounts enormously for its rapidly growing population. More job opportunities in the city attract people from in and around Chennai to come and settle here. Multinational companies have already set up their branch offices in Chennai leading to more people being hired by these companies. So the Population of Chennai (Fig. 3) has grown rapidly in the last 20 years due to its major industrialization and tremendous growth.

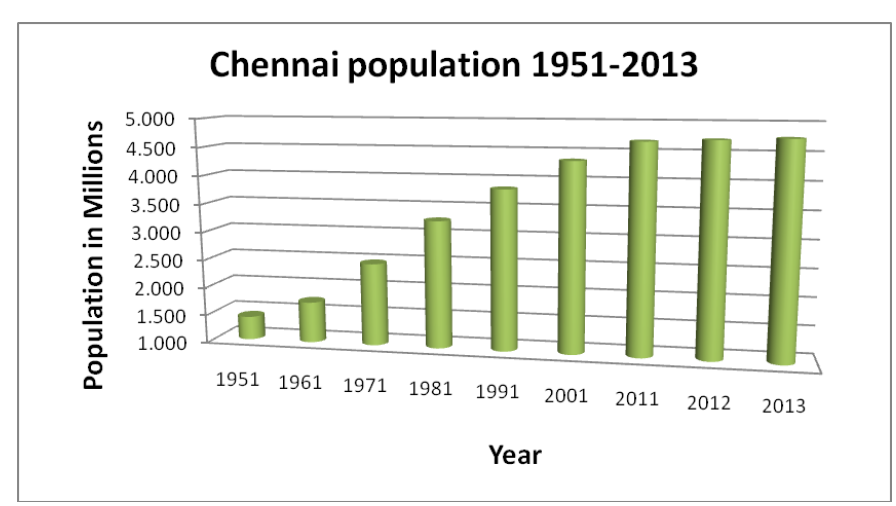

Fig. 3. Growth of Chennai population

The trend of groundwater level in Chennai city 


\section{International Journal of Engineering Applied Sciences and Technology, 2019 Vol. 4, Issue 3, ISSN No. 2455-2143, Pages 99-104 \\ Published Online July 2019 in IJEAST (http://www.ijeast.com)}

The cycle of floods followed by acute drought and its impact on water scarcity in Chennai was most acute in the years 1987 and 1993. In the year 1986, a major drought hit Chennai City. Rainfall recorded was only $40 \%$. The total available water in the three lakes of the City was only $17 \%$. The total available water in the three lakes of the City was only $17 \%$. Necessitation of Legislation to regulate the extraction of groundwater. In 1988 groundwater level in Chennai was about 8 meters in depth but in 2007 it went up to 4.08 meter. The commercial exploitation from 1988 to 1996 was more.

Figure 4 shows the groundwater level fluctuation during 1987 to 2007. From the data 1996 to 1999, Groundwater extraction coupled with groundwater regulation results rises in water level. In 2001 to 2004, a Peak drought / Dependence on groundwater source was the maximum percentage of recharge from rain almost nil.

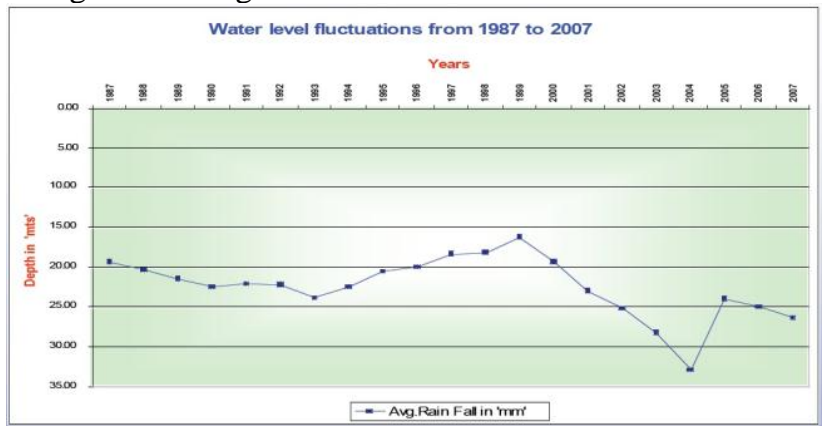

Fig. 4. Groundwater level fluctuation

\section{Rainfall variability}

During the month of October, November, and December, the northeast monsoon mainly contributes the rainfall for the district. Most of the precipitation occurs in the form cyclones caused due to depressions in the Bay of Bengal. The southwest monsoon rainfall is erratic and summer rains are negligible. The average annual rainfall of the study area is $1200 \mathrm{~mm}$ (1978-2008) [17]. Chennai district appreciates a tropical climate with a mean annual temperature of 24.3 to $32.9^{\circ} \mathrm{C}[18]$.

The temperature is usually in the range from 13.9 to $45^{\circ} \mathrm{C}$. Range of the humidity is from 65 to $84 \%$ while sea breeze in the evening hours is a blessing to combat the high temperature and humidity during summer months [19]. Rainfall climatology brings out the general pattern and characteristics of rainfall of a particular region [20]. From figure 6, there was a downward trend in rainfall. During 2005 to 2008 shows an increasing trend and a sudden fall during 2009. From 2010 to 2013 there was a long gradual decreasing rainfall occurs. It led to water level decreasing in Redhills Reservoir.

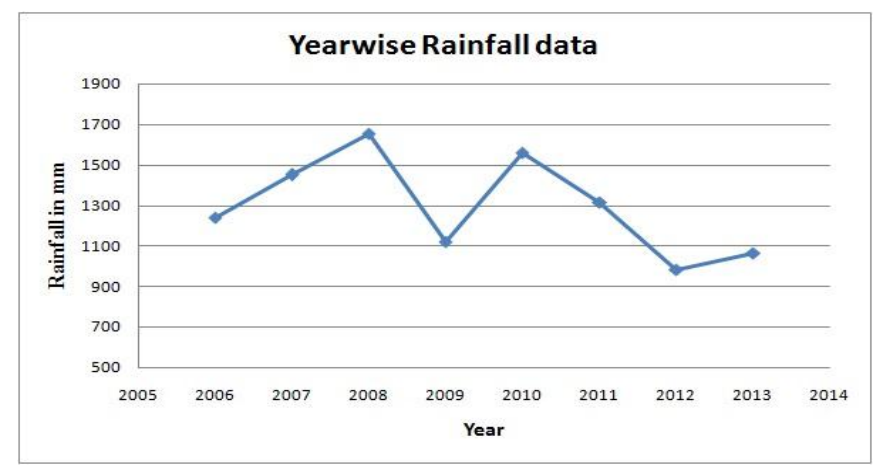

Fig. 5. Year wise rainfall data

\section{Reservoir water level fluctuation}

With reference to the above rainfall variability, the water level in reservoir change during the month of May and September. During the pre-monsoon season (May) the water of the reservoir gone down from $45 \mathrm{ft}$ to $39 \mathrm{ft}$. This induces groundwater scarcity of area which is using the water from the Redhills reservoir. In September there was a decreasing trend of water level occur but not in a large amount compared with May.

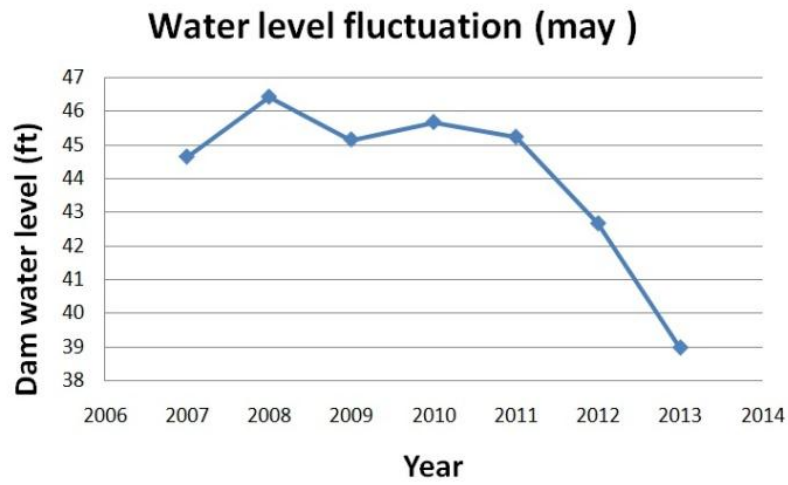

Fig. 6. Redhills reservoir water level fluctuation in May

Figure 7. Shows the outflow of water from the dam during May there were no much changes 2006 to 2010. After 2010 the sudden increase in the necessity of water raises to nearly 200 cusecs. From 2010 onward there was no decreasing trend of outflow is noticed. During September (Fig. 8) from 2006 to 2010, some normal fluctuation in outflow but in 2013 the need for water from the reservoir was going up to 100 cusecs. 
International Journal of Engineering Applied Sciences and Technology, 2019

Vol. 4, Issue 3, ISSN No. 2455-2143, Pages 99-104

Published Online July 2019 in IJEAST (http://www.ijeast.com)

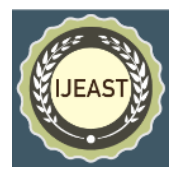

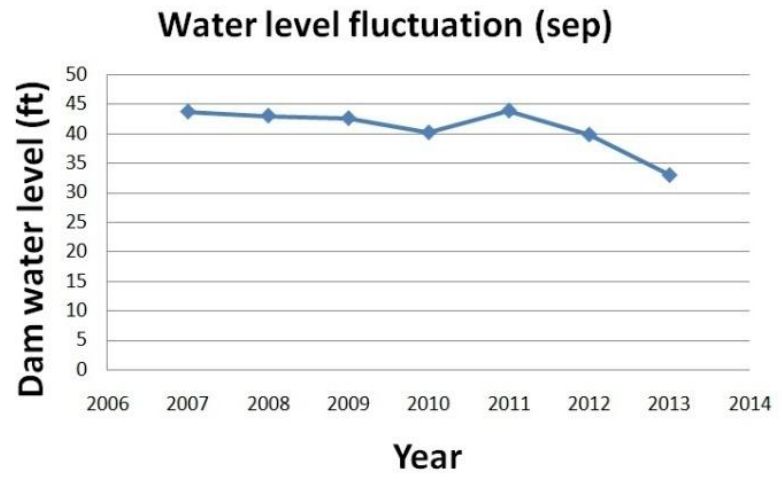

Fig. 7. Redhills reservoir water level fluctuation in September

\section{Dam water Outflow in may} (cusecs)

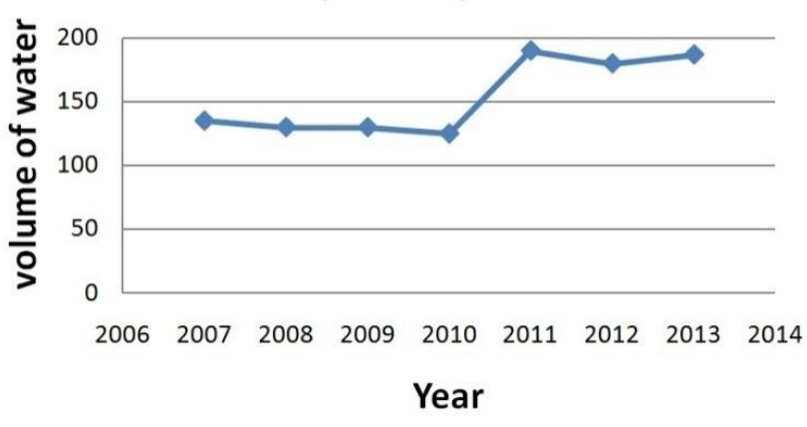

Fig. 8. Redhills reservoir water outflow in May

Duan et al (2011) [21] have studied the water level fluctuation in the semi-arid environmental and inferred the effects on the vegetations. As per the data, the population is gradually increased similarly gradual rainfall is also decreased. According to Manal and Macro (2008) [22] Waterlevel fluctuations (WLF) in lakes and rivers depends on their extent, frequency, and duration are dominant forces controlling the functioning of these ecosystems.

As per the dam outflow is concerned, from 2010, it is suddenly increased even though the rainfall level decreased. The High population and necessarily of water is needed may be the causes. these findings also supported by Tamar Zohary and Ilia Ostrovsky, droughts with declining river inflows over the region have led to a multiannual drawdown of its water level [23]. In addition to drawdown and other forms of water exploitation, climate change models predict increased occurrence of extreme events such as flooding and extended droughts [24], which will further magnify the seasonal and multiannual amplitude of WLF in lakes and alter their temporal dynamics [25].
In drought years, such as 1999 and 2003, the runoff generated was seen to be very low and this resulted in the feed reservoir remaining dry for the most part of the respective periods. As a consequence, the piped water supply was stopped for a significant period during these years in the Chennai city [26]. Lakes with clear water are much more resistant against fluctuating water levels due to the wider productive zone as compared to lakes with humid water [27, $28]$.

\section{Dam water Outflow in Sep (cusecs)}

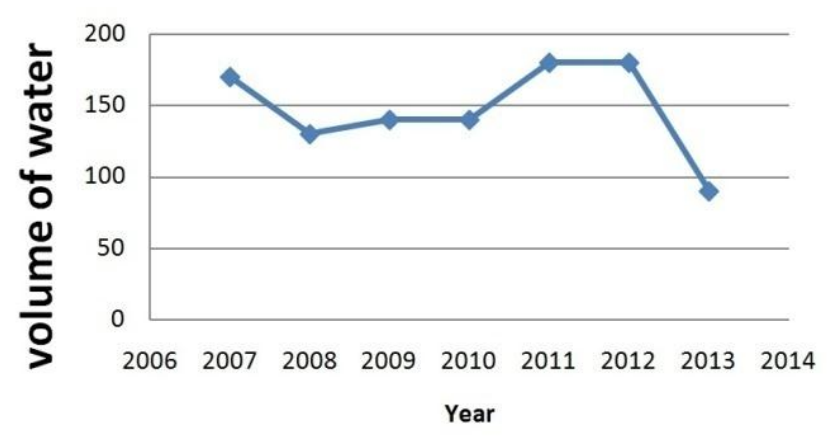

Fig. 9. Redhills reservoir water outflow in September

\section{CONCLUSION}

Based on this study, it is quite clear that the Red Hills Reservoir is a valuable resource that will continue to be transformed from natural wonders into commodities in the future. Our predictions for the future are that there will need to be greater protection and enforcement for the Lakes to protect them from potentially devastating human impacts. Flooding reveals how we relate to our environment and we as a society need to be conscious as to how our patterns of living are affected and are correlated to our environment. Climate change is a large indicator of the future of the Red Hills Reservoir and it will have impacts like low water levels that affect many facets of the world and its ecosystems.

\section{ACKNOWLEDGMENT}

The authors are thankful to Dr. M. Suresh Gandhi, Associate Professor, Department of Geology, and University of Madras for his valuable comments and criticism to improve this paper.

\section{REFERENCE}

[1] Water Scarcity (2013). International Decade for Action 'Water for Life' 2005-2015. 


\section{International Journal of Engineering Applied Sciences and Technology, 2019 Vol. 4, Issue 3, ISSN No. 2455-2143, Pages 99-104 \\ Published Online July 2019 in IJEAST (http://www.ijeast.com)}

[2] Falkenmark and Lindh (2009) quoted in UNEP/WMO. "Climate Change 2001: Working Group II: Impacts, Adaptation and Vulnerability". UNEP.

[3] Larsen, Samuel, T. L. (2009). "Lack of Freshwater Throughout the World". Evergreen State College.

[4] Water in a Changing World (2010). UN Water Development Report 3, (World Water Assessment Programme, 2009).

[5] Richard Connor, Jean-Marc Faures and Johan Kuylenstierna. (2010). "Chapter 7, Evaluation of water use," Water in a changing world, (World Water Development Report 3, 2009).

[6] Vital Water Graphics. (2010). An overview of the state of the world's fresh and marine waters: 2nd Edition, (United Nations Environment Programme: 2008).

[7] Distilled Demographics Video (2010). The Death Rate, Population Reference Bureau.

[8] Wetzel R. G. (1990). Reservoir ecosystems: Conclusions and speculations. In: Reservoir Limnology: Ecological Perspectives (edsK. W. Thornton, B. L.Kimmel \& F. E. Payne), Wiley, New York. (pp. 227-38).

[9] Water Stress. Retrieved 20 October 2013.

[10] Pandey A., Chowdary V. M., Mal B. C., and P. P. Dabral. (2003). Estimation of runoff for an agricultural watershed using SCS Curve Number and Geographic Information System. Map India. Online. URL: http://www. gisdevelopment. net/application/agriculture/soil/pdf/48.Pdf.

[11] Water Scarcity (2013) | Threats | WWF.

[12] Freshwater: lifeblood of the planet. (2013). peopleandplanet.net (11 November 2002).

[13] Subhashini R., and Ancy S. (2013). Measuring the temperature of Chennai using satellite images. International Journal of Innovative Research in Computer and Communication Engineering.

[14] Deepa K., and Krishnaveni M. (2012). Suitable Site Selection of Decentralised Treatment Plants Using Multicriteria Approach in GIS. Journal of Geographic Information System,

[15] Nachimuthu K. (2011). System simulation model based road accidents and its cost prediction, Chennai, Lulu.com.

[16] Indiaonlinepages.com. (2019). Population of Chennai 2019- Chennai Current Population. [online] Available at: http://www.indiaonlinepages.com/population/chennaicurrent-population.html.

[17] Balakrishnan T. (2008). District groundwater brochure Chennai district Tamil Nadu. Government of India Ministry of Water Resources Central Ground Water Board South Eastern Coastal Region Chennai.
[18] CGWB Technical Report (2008). District groundwater brochure Chennai district Tamil Nadu (pp.1-19).

[19] Raj Y. E. A., Sankaran P. V., and Ramakrishnan B. (2002). Climatological characteristics of sea breeze parameters at Chennai. Mausam.

[20] John and Ekatha Ann. (2012). "Disaster body for panel to monitor highrises in Chennai". The Times of India (Chennai).

[21] Yadav and Priya. (2013). "Soon, power from ancient rocks". The Times of India (Chennai).

[22] Sastri A.S.R.A.S., Divakar Naidu, Somnath Choudhury. (2009). Agro-topo Climatological Studies for Crop Planning -A Case Study for the Northern Hills Agroclimatic Zones of Chattisgarh State, Journal of Agrometeorology, (pp.33-36).

[23] Duan L., Liu T., Wang X., Luo Y., Wang W. and Liu X. (2011). Water table fluctuation and its effects on vegetation in a semiarid environment. Hydrol. Earth Syst. Sci. Discuss., (pp.3271-3304).

[24] Leira, Manel, Cantonati and Marco. (2008). Effects of water-level fluctuations on lakes: an annotated bibliography. Hydrobiologia, (pp. 171).

[25] Tamar Zohary and Ilia Ostrovsky. (2011). Ecological impacts of excessive water level fluctuations in stratified freshwater lakes. International Society of Limnology 2011. Inland Waters, (pp.47-59).

[26] Intergovernmental Panel on Climate Changes [IPCC] (2007). Summary for policymakers. In: Solomon S, Qin D, Manning M, Chen Z, Marquis M, Averyt KB, Tignor M, Miller HL, editors. Climate change 2007: The physical science basis. Contribution of Working Group I to the Fourth Assessment Report of the Intergovernmental Panel on Climate Change. Geneva (Switzerland).

[27] Magnuson J.J., Webster K.E., Assel R.A., Bowser CJ., Dillon PJ., Eaton JG., Evans HE., Fee EJ., Hall RI., Mortsch LR. et al. (1997) Potential effects of climate changes on aquatic systems: Laurentian Great Lakes and Precambrian Shield Region. Hydrol Process (pp. 825871).

[28] Geena G. B. and Ballukraya P.N. (2011). Estimation of runoff for Red hills watershed using SCS method and GIS. Indian Journal of Science and Technology. 